\title{
Extensive Fall Wandering of Immature Horned Owl and Magpie
}

by C. Stuart Houston, Newton Highlands, Mass., U.S.A.

Three banding recoveries showing extensive fall wandering by immature birds, two Great Horned Owls and one Black-billed Magpie, seem of interest since these birds belong in the category of "year-round residents." A nestling Great Horned Owl banded three miles west of Vonda, Saskatchewan (with the assistance of Bernie Gollop and Jim Slimmon), on May 24, 1961, was reported shot by a hunter (letter of November 13, 1961) near the Sheyenne River, near Sheldon, North Dakota, about 570 miles southeast of where it was banded. A nestling Great Horned Owl banded six miles south of Dilke, Saskatchewan (with the assistance of Wilfred McArton and J. B. Belcher), on May 20, 1961, was shot during the 1961 fall hunting season near Willow City, North Dakota, or about 270 miles southeast of where banded. A nestling Black-billed Magpie banded eight miles north and one mile west of Zehner, Saskatch- ewan (with the assistance of George Chopping), was shot by a hunter October 29, 1951, near Milton, North Dakota, about 320 miles southeast of where banded.

These birds were all immatures and all three went southeast. Of a total of 29 recoveries from 303 banded Great Horned Owls, and five recoveries from 109 Black-billed Magpies, the remainder have been within 50 miles of the place of banding, with only one other exception. This was a Great Horned Owl recovered 19 months later in Minnesota some 450 miles southeast of the banding locality, as already reported (Blue Jay $16: 60,1958)$. These fragmentary records suggest to me that perhaps ten per cent of young Great Horned Owls and Black-billed Magpies may wander far afield from Saskatchewan, usually in their first year of life. A need for further banding studies seems indicated.

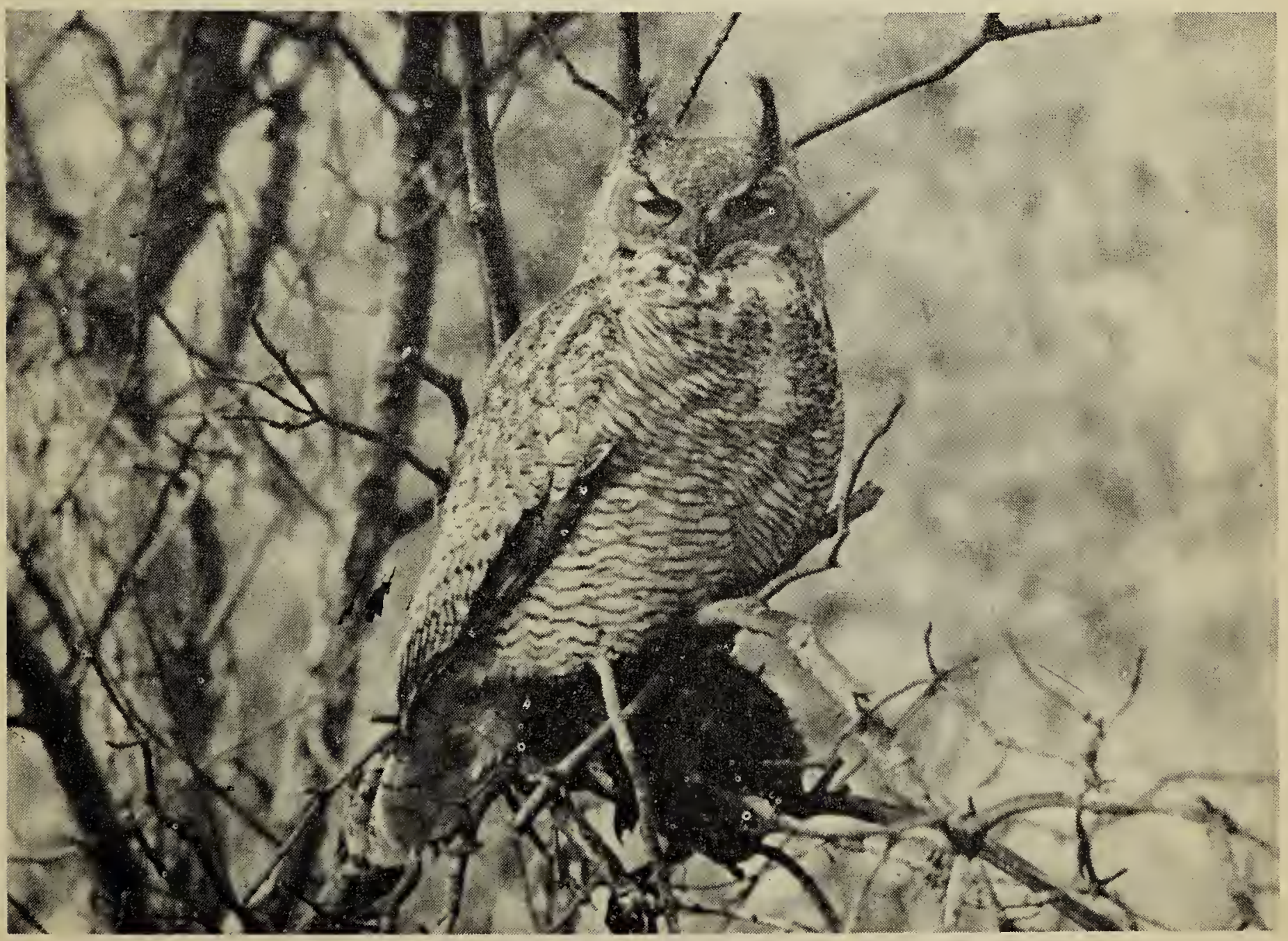

